\title{
Satisfaction and adherence of patients with amputations to physiotherapy service at public hospitals in KwaZulu-Natal, South Africa
}

Chetty Verusia , Dunpath Tanuja, Meghnath Simira, Mothalal Sarisha, Sewmungal Varuna, Kunene Ursula, Ntshakala Thalente

Physiotherapy Department, Westville, UKZN, Private Bag X54001, Durban, 4000

\section{Abstract}

Background: Individuals who have undergone a lower limb amputation require comprehensive rehabilitation from the multidisciplinary team to ensure optimal treatment outcomes and social integration. Physiotherapists play a pivotal tole in the mats te role can inform practice and improve service delivery of rehabilitation within resource poor settings such as South Africa.

Objectives: To determine the level of satisfaction with physiotherapy services rendered to acute and sub-acute in-patient with lower limb amputations and to explore factors affecting adherence to physiotherapy intervention.

Methods: A prospective survey of 35 patients with lower limb amputations from four public hospitals in South Africa wa undertaken. A modified version of the Hampstead rehabilitation centre patient satisfaction questionnaire was utilised.

Results: Majority of participants were satisfied with the physiotherapy services whilst a few reported dissatisfaction. Three themes emerged whilst exploring the patients' experience relating to adherence to physiotherapy programmes. Themes included service delivery, patient-therapist interaction and participation barriers and facilitators.

Conclusion: Recommendations aimed to improve quality of care and healthcare outcomes thereby enhancing the participants' adherence to the physiotherapy programme.

Keywords: amputation, patient satisfaction, patient adherence, physiotherapy.

\section{DOI: http://dx.doi.org/10.4314/ahs.v15i2.19}

\section{Introduction}

Patient satisfaction within the rehabilitation framework needs to be established as it affects the success of management and adherence to treatment regimes. Satisfaction with healthcare services often impacts the quality of care and has consequent effects on the marketability of essential services. ${ }^{1}$ Although, patient satisfaction is multidimensional and can be jaded by emotion, rehabilitation professionals can use the feedback to improve or modify practice.

\section{Corresponding author:}

Chetty Verusia

Physiotherapy Department

Westville, UKZN, Private Bag

X54001, Durban, 4000

Email: chettyve@ukzn.ac.za

Cell: 0748905279

Tel (H): 0314647631

(W): 0312607741
Furthermore, by exploring the factors that affect adherence to rehabilitation, professionals can understand the effect of emotion and personal experience on the service offered. Patients with lower limb amputations are among the rehabilitation recipients of ongoing care. They have multiple physical, psychological, en vironmental and socio-economic barriers and require patient-centred, comprehensive rehabilitation from the multidisciplinary team to ensure optimal treatment outcomes, social integration and economic self-sufficiency. Physiotherapists are an essential component of the multidisciplinary team ${ }^{2}$, and offer patients the future of optimal function in daily life. Patient co-operation and willingness to participate in the rehabilitative process is a key element of physiotherapy, as it is a scope of practice involved with the functioning of individuals, as well as optimizing independency ${ }^{3}$.

The subjective nature of patient satisfaction research in rehabilitation contributes to an individuals' focus on the emotive paradigm. Patients who are positive about treatment tend to adhere to the therapy regimes and offer good feedback to other individuals regarding the benefit of such services. ${ }^{1,2}$ Facilitators of patient satisfaction highlighted in the literature was the development of an effective communication basis with the therapist; the patient is treated with humility and acknowledged as an individual and when the therapist displays confidence in the patient as well as themselves. ${ }^{4}$ Patients who are pessimistic may be inclined to perpetuate negative experiences to friends and family and may not adhere to rehabilitation routines. ${ }^{1,2}$ By gaining an understanding of patient perspectives the authors of this paper sought not only to determine the satisfaction of patients but further sought to explore factors that affect adherence to rehabilitation.

\section{Methodology}

Design: In order to achieve the objectives of this study, the authors chose a prospective cross-sectional survey design with use of both open-ended and closed-ended questions.

Recruitment and selection of participants: Purposive sampling was employed in the selection of fou public hospitals in the province of KwaZulu-Natal, South Africa. All four sites service amputee in-patients in the acute and sub-acute phases of rehabilitation.

Ethical considerations: Ethical clearance was obtained from the University of KwaZulu-Natal and permission was granted from the relevant authorities at study settings. Voluntarily consent for participation in the study was confirmed and no incentives were offered for participation in the study.

Inclusion criteria: Thirty-five adult in-patients with lower limb amputations met the inclusion criteria whic included the following: patients had to have received physiotherapy for more than two sessions; they had to be within the acute and sub-acute stages of healing and had to be cognitively sound.

Data collection instrument: A modified version of the Hampstead rehabilitation centre patient satisfaction questionnaire ${ }^{2}$ was utilised. For purposes of this study, instrument was translated into isiZulu prior to a pilot study. The survey comprised twelve closed-ended questions that required responses using a five point Likert scale on satisfaction of physiotherapy services. The questions were positively phrased which deferred from the original survey as the negative questions proved to be a challenge for participants during the pilot stage of this study. Content validity was ensured through having the questionnaire appraised by researchers in the field. The final data collection instrument consisted of three sections. Section 1 had questions related to demographic data. Section 2 included the modified Hampstead rehabilitation centre patient satisfaction questionnaire ${ }^{2}$ and Section 3 included 4 open-ended questions related to factors that affect adherence to treatment.

Data analysis: With the assistance of a statistician, the data from the questionnaire was analysed using the Statistical Package for Social Sciences (SPSS) version 21.0 and was reflected as descriptive statistics. Cronbach's Alpha which measures internal consistency of the questionnaire was also computed. The authors opted for a thematic analysis ${ }^{6}$ for the four open-ended questions. Trustworthiness and credibility were ensured during the qualitative analysis stage to ensure rigor. ${ }^{6}$

\section{Results}

Thirty five patients participated in the study, 14 were female and 21 male. Majority of the participants were married. The mean age was calculated to be 56 years. Twenty four patients were of African ethnicity, 8 Indian, 2 White and 1 of Mixed descent. One participant had a tertiary education while the other patients were unemployed or had low income jobs.

Table 1 illustrates the results of the closed-ended questions and the frequencies of responses. The general trend reflected that majority of the participants were satisfied with the Physiotherapy service. Cronbach's alpha was computed to determine the internal consistency of responses and revealed a score of 0.847 which indicates a high level of consistency. 
Table 1: Patient satisfaction with physiotherapy services

\begin{tabular}{|c|c|c|c|c|c|}
\hline & $\begin{array}{l}\text { Strongly } \\
\text { agree }\end{array}$ & Agree & Unsure & Disagree & $\begin{array}{l}\text { Strongly } \\
\text { disagree }\end{array}$ \\
\hline $\begin{array}{l}\text { 1. My physiotherapist } \\
\text { gave me good advice } \\
\text { and treatment }\end{array}$ & $25.7 \%$ & $57.1 \%$ & $0 \%$ & $11.4 \%$ & $5.7 \%$ \\
\hline $\begin{array}{l}\text { 2. I did receive enough } \\
\text { physiotherapy }\end{array}$ & $17.1 \%$ & $42.9 \%$ & $5.7 \%$ & $31.4 \%$ & $2.9 \%$ \\
\hline $\begin{array}{l}\text { 3. My physiotherapist } \\
\text { listened to my } \\
\text { concerns }\end{array}$ & $25.7 \%$ & $60 \%$ & $5.7 \%$ & $8.6 \%$ & $0 \%$ \\
\hline $\begin{array}{l}\text { 4. My physiotherapist } \\
\text { answered } \\
\text { questions in a way } \\
\text { that I could } \\
\text { understand }\end{array}$ & $28.6 \%$ & $62.9 \%$ & $5.7 \%$ & $2.9 \%$ & $0 \%$ \\
\hline $\begin{array}{l}\text { 5. My physiotherapist } \\
\text { involved me in } \\
\text { decisions regarding } \\
\text { my physiotherapy } \\
\text { care }\end{array}$ & $28.6 \%$ & $42.9 \%$ & $14.3 \%$ & $14.3 \%$ & $0 \%$ \\
\hline $\begin{array}{l}\text { 6. My physiotherapist } \\
\text { provided me with } \\
\text { adequate explanations } \\
\text { or instructions } \\
\text { regarding r my } \\
\text { treatment }\end{array}$ & $37.1 \%$ & $37.1 \%$ & $2.9 \%$ & $22.9 \%$ & $0 \%$ \\
\hline $\begin{array}{l}\text { 7. My physiotherapist } \\
\text { involved me in } \\
\text { physiotherapy plans } \\
\text { during my stay }\end{array}$ & $17.1 \%$ & $48.6 \%$ & $11.4 \%$ & $22.9 \%$ & $0 \%$ \\
\hline $\begin{array}{l}\text { 8. My physiotherapist } \\
\text { was kind, caring and } \\
\text { courteous }\end{array}$ & $37.1 \%$ & $62.9 \%$ & $0 \%$ & $0 \%$ & $0 \%$ \\
\hline $\begin{array}{l}\text { 9. } \begin{array}{lr}\text { The timing and } \\
\text { location } \\
\text { physiotherapy } \\
\text { convenient }\end{array} \\
\text { was }\end{array}$ & $28.6 \%$ & $54.3 \%$ & $11.4 \%$ & $5.7 \%$ & $0 \%$ \\
\hline $\begin{array}{l}\text { 10. The physiotherapy } \\
\text { treatment area was } \\
\text { neat and clean }\end{array}$ & $40 \%$ & $45.7 \%$ & $11.4 \%$ & $2.9 \%$ & $0 \%$ \\
\hline $\begin{array}{l}\text { 11. My privacy, dignity } \\
\text { and comfort during } \\
\text { physiotherapy } \\
\text { considered }\end{array}$ & $40 \%$ & $51.4 \%$ & $0 \%$ & $5.7 \%$ & $2.9 \%$ \\
\hline $\begin{array}{l}\text { 12. Overall, I found the } \\
\text { physiotherapy service } \\
\text { satisfactory }\end{array}$ & $31.4 \%$ & $57.1 \%$ & $8.6 \%$ & $2.9 \%$ & $0 \%$ \\
\hline
\end{tabular}

The data from the open-ended questions are reflected livery, Patient- practitioner interaction and Participation in Table 2 as three emergent themes namely: Service de- barriers and facilitators.
Table 2: Thematic representation of patient's experiences with physiotherapy services

\begin{tabular}{|c|c|c|c|}
\hline Theme & Sub-Theme & Category & Node \\
\hline $\begin{array}{l}\text { Service } \\
\text { Delivery }\end{array}$ & $\begin{array}{l}\text { Conduct and } \\
\text { Professionalism }\end{array}$ & $\begin{array}{ll} & \text { Well equipped } \\
& \text { Knowledgeable } \\
& \text { Above and Beyond } \\
& \text { Holistic approach } \\
& \text { Respect }\end{array}$ & $\begin{array}{l}\text { "Throughout my physiotherapy } \\
\text { sessions my therapist made sure I was } \\
\text { okay and managing well with my } \\
\text { therapy. The physiotherapist always } \\
\text { treated me with respect and in a } \\
\text { dignified manner. They show genuine } \\
\text { care and ensure my privacy at all } \\
\text { times."(Code 23) }\end{array}$ \\
\hline \multirow[t]{2}{*}{$\begin{array}{l}\text { Patient- } \\
\text { Practitioner } \\
\text { Interaction }\end{array}$} & $\begin{array}{l}\text { Communication is } \\
\text { key }\end{array}$ & 4. Everyday language & $\begin{array}{l}\text { "the physiotherapist always greets me } \\
\text { with a smile and explains everything } \\
\text { that I need to know in a way I can } \\
\text { understand, they do not use } \\
\text { complicated medical words when } \\
\text { talking to me."(Code 25) }\end{array}$ \\
\hline & Motivation & $\begin{array}{ll} & \text { Progress } \\
\text { feedback } & \text { and } \\
& \text { Benefits } \\
\text { exercise } & \text { of }\end{array}$ & $\begin{array}{l}\text { "If I am making any progress in my } \\
\text { physiotherapy, my therapist involves } \\
\text { me and provides feedback to me, and I } \\
\text { like this... They always involve me in } \\
\text { my treatment sessions and include me } \\
\text { in the decisions pertaining to my } \\
\text { care."(Code 26) }\end{array}$ \\
\hline \multirow[t]{3}{*}{$\begin{array}{l}\text { Participation } \\
\text { facilitators and } \\
\text { barriers }\end{array}$} & $\begin{array}{l}\text { Organizational and } \\
\text { environmental }\end{array}$ & $\begin{array}{l}\$ \text { Use of correct } \\
\text { equipment } \\
+ \text { Privacy } \\
\text { \& Sufficient } \\
\text { treatment space } \\
\text { \& Adequate treatment } \\
\text { time }\end{array}$ & $\begin{array}{l}\text { "I think they should spend a bit more } \\
\text { time with patients. I have been treated } \\
\text { for five minutes. I get to move my leg } \\
\text { up and down, in and out... I think } \\
\text { overall they need to spend more time } \\
\text { with patients." (Unhappy tone)(Code } \\
\text { 15) } \\
\text { " the equipment is very old and they } \\
\text { should get new stuff for us, because } \\
\text { there is so many of us" (Code 24) } \\
\text { "They show genuine care and ensure } \\
\text { my privacy at all times."(Code 23) }\end{array}$ \\
\hline & Therapy & 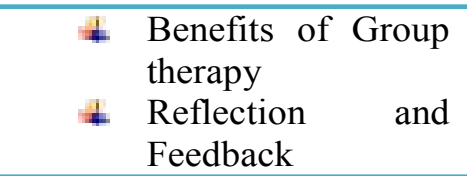 & $\begin{array}{l}\text { " the class is enjoyable because we } \\
\text { interact with each other and we make } \\
\text { jokes, it is fun...I enjoy the amp class } \\
\text { and I benefit a lot from it" (Code 18) }\end{array}$ \\
\hline & Personal & $\begin{array}{ll}\ddagger & \text { Pain experience } \\
\$ & \text { Psychological } \\
& \text { factors } \\
& \text { Stigma } \\
\$ & \text { Social integration } \\
& \text { Self-goals }\end{array}$ & $\begin{array}{l}\text { "Sometimes I wake up in the morning } \\
\text { feeling down and not feeling like doing } \\
\text { the exercises. Sometimes the } \\
\text { medication they give me makes me feel } \\
\text { tired and feeling like sleeping. The } \\
\text { pain from the wound makes me stop } \\
\text { doing the exercises." (Code 14) } \\
\text { "Maybe I'm lazy. It's a very } \\
\text { demotivating experience to lose a limb } \\
\text { and I feel more discouraged not to do } \\
\text { the exercises. I felt and still feel } \\
\text { terrible. In think I should have been } \\
\text { referred to a psychologist." (Code15) } \\
\text { "We do not go to the gym, I do not } \\
\text { know why. When we are doing the } \\
\text { exercises everyone see me and laugh at } \\
\text { me when I lift up the stump." (Code 11) }\end{array}$ \\
\hline
\end{tabular}




\section{Discussion}

Results of Survey

Results of the survey indicate that patients were genwho are satisfied with the service delivery are adherent to therapy regimes and will in turn perpetuate positive reference and referrals to the rehabilitation practice ${ }^{1}$. A study by Stiller ${ }^{2}$ iterates the necessity for assessing patient satisfaction as it is a valuable component in the evaluation of health-care outcomes in healthcare settings. A positive outcome indicates a good standard of physiotherapy care but the recommendations need to be addressed to optimize quality of care offered in practice.

In an endeavour to explore amputee in-patients satisfaction and adherence to the physiotherapy service three pertinent themes emerged i.e. Service delivery, $\mathrm{Pa}$ tient- practitioner interaction and participation barriers and facilitators.

\section{Service delivery}

The three sub-themes that emerged included the therapist's conduct and professionalism, protection and safety and lastly collaboration and communication. Within the therapists' conduct and professionalism sub-theme, therapist are considered essential particularly in situations where patients' privacy is threatened. Respect and empathy were expressed as fundamental in quality care as cited in another study. ${ }^{9}$ The bioethical principle of non-maleficence where health care providers should avoid causing harm to their patients was echoed, by the therapist's conduct in this study. They ensured patients' safety was maintained as a priority in management. ${ }^{10}$ The first intent to do no harm is the foundation of medical ethics in every situation, and results subsequently lead to the development of a mutual trusting relationship between patient and physiotherapist which ensured satisfaction with the service. ${ }^{10}$ On the contrary this principle was not upheld in the management of a single patient in this study and this resulted in feeling of fear and dissatisfaction during the intervention sessions.

\section{Patient-practitioner interaction}

The communication between the patient and practitioner was explored as this influenced patient satisfaction and adherence to physiotherapy treatment. Effecerally satisfied with the physiotherapy service. Patients the personal and professional qualities of the physiotive communication consisted of educating patients on heir condition, clear instructions and offering feedback to patients on their progress. Analogously pound a positive correlation with patient-practitione information, education and time spent with the patient reflected greater patient fulfilment. Patients' were encouraged by the therapists' use of lay language and empathetic listening skills. Congruently, Brokalaki ${ }^{12} \mathrm{em}-$ phasized patients distaste for technical language, poor feedback and depersonalized care when communicat ing with their practitioner. The patients in this study believed that gaining feedback through constructive reporting offered them a clear understanding of their progress continuum. When these were ensured, patient satisfaction and adherence was secured.

Motivation was a driving force that encouraged patients' to adhere to therapy. Patients showed appreciation toward their physiotherapists when the therapist encouraged their active involvement in their personal health and care. As a result, motivation and feedback offered to patients' on their progress, positively affected compliance to their ward exercise program. Functional outcome can be affected by patients' levels of motivation and in turn can result in positive rehabilitation outcomes of treatment $t^{13}$. A rehabilitation regimen was studied in patients with bilateral amputation of lower extremities and once again motivation reappeared as a contributing factor ${ }^{14}$.

\section{Participation barriers and facilitators}

The theme of Participation barriers and facilitators explored organizational and environmental factors, the therapy rendered to patients and personal factors. This theme encompassed the barriers and facilitators that impeded satisfaction and thus affected adherence. The organizational and environmental subtheme incorporated various factors that contribute to an effective therapy session. This included using the correct equipment, ensuring privacy, ensuring sufficient treatment space and adequate treatment time. Petek Ster ${ }^{15}$ in thei study also proposed that the duration of treatment and consultation time plays an important role in the satisfaction of patients. The study argued that treatment time is ing treated, organizational aspects and the relationship the therapist shares with the patient. ${ }^{15}$ In Stiller's ${ }^{2}$ study recommendations to improve the physiotherapy service interaction and satisfaction with therapy. The shared

included the equipment; the study did-not detail the challenges with the availability or suitability of equipment. In this study however, participants complained about the lack of equipment as well as the availability during therapy sessions which is common in resource poor settings.

Focusing on ensuring privacy, patients were encouraged by the therapists' handling and maintenance of their privacy during rehabilitation sessions. Karro ${ }^{16}$ emphasized the importance of patient privacy in securing the patient's dignity and confidentiality. The South African Patients Right Charter states that "Privacy is a right", thus individuals' privacy should always be ensured and protected by the healthcare provider.

Personal barriers to adherence to rehabilitation included the aspects that affected the well-being of participants and included pain experienced, feelings of being emotionally burdened, stigmatization and psychological issues. Pain often caused patients' to be averse to exercises. Although pain is a barrier to rehabilitation and limits function ${ }^{18}$, it is a factor that can be managed by physiotherapists. A study of in-patient physiotherapy rehabilitation of amputee patients proved to reduce bodily pain and aided in patients' functional ability ${ }^{19}$.

A study by Horgan and MaclaChlan ${ }^{20}$ stated that in the acute phase post amputation psychological factors such as depression contributed to patients having lower levels of mobility, greater levels of activity restrictions, increased feelings of vulnerability and poor self-rated health. However, a study of amputee patients receiving psychosocial rehabilitation for the management of pain medication as well as behavioural problems proved to be successful. ${ }^{21}$ The referral of patients' to psychosocial therapy in this study would aid rehabilitation. Furthermore, issues of stigma and emotional grief could be addressed with psychosocial rehabilitation by a trained professional within the multidisciplinary team. ${ }^{2}$

A patient-centred, multi-disciplinary team approach is crucial in addressing the emotional, social and physical needs of amputee patients. ${ }^{2}$ Some patients in this study were not referred timeously to other active members of the team despite the evident need; this implied a lack of effective collaboration between healthcare professionals. A study by Chetty and Maharaj ${ }^{22}$ identified the importance of teamwork but also added that impediments collaboration were communication barriers and lack of understanding of roles within the team.

Amongst the facilitators of participation in therapy was patients' setting their own self-goals. This ensured that they were motivated to perform their exercise programme. Stiller ${ }^{2}$ recommended that patient and practitioner should work together in setting achievable goals for rehabilitation and should be guided by patient's expectations of therapy. Other patients were motivated socially to return home so that they could be reunited with their friends and family. Furthermore, many of the patients were the breadwinners of their household hence they were obligated to speedily recover so they could return to work and provide for their families. Pre-operative employment proved to favourably affect the post-operative functional ability of patients in a study by Pohjolainen and Alaranta ${ }^{23}$. Career path and achievement also positively influences amputee patient's psychosocial status and subsequently will affect patients' well-being and health. ${ }^{24}$ Some patients in the study adhered to therapy regimens as they were drivn to achieve their premorbid state of functioning as self-sufficient individuals. ${ }^{24}$

The design of the therapy regime was influential on the adherence of patients. A stimulating exercise programme was adhered too and a lack of lustre regime was abandoned. Group therapy was a major contributor to patients' adherence with regards to their exercise regimen. It promoted a feeling of social support and the shared experiences kept patients motivated. Results in the study by Lubcke ${ }^{10}$ were in keeping with the current study as participants' felt encouraged and supported when exercising with individuals with similar conditions.

\section{Conclusion}

The findings in the study support the importance of evaluating patient satisfaction and factors affecting adherence in offering quality rehabilitation in health care. Although it is specific to the context of the study, it is valuable in emphasizing the importance of evaluating health care delivery. It provides healthcare practitioners' with tools to not merely evaluate care but to further improve the standard of delivery. ${ }^{2}$ The study could be undertaken at regular intervals at single sites incorporating multiple service providers as an essential measure to impact health care outcomes in resource poor settings such as South Africa. 


\section{Conflict of interest}

The authors report no real or perceived vested interests that relate to this article (including relations to pharmaceutical companies, biomedical device manufacturers, grantors, or other entities whose products or services are related to topics covered in this manuscript) that could be constructed as a conflict of interest.

\section{References}

1. Keith RA. Patient satisfaction and rehabilitation services. Arch Phys Med Rebabil 1998; 79:1122-8.

2. Stiller KGC, Drury C. Evaluating inpatient satisfaction with a physiotherapy service: A Rehabilitation Centre Survey. International Journal of Therapy and Rehabilitation 2009; 16(7):376-83

3. Hills R, Kitchen S. Toward a theory of patient satisfaction with physiotherapy: Exploring the concept of satisfaction. Physiotherapy Theory and Practice 2007; 23(5): 243-254.

4. Mangset M, Dahl T E, Forde R, Wyller T B. 'We're just sick people, nothing else'... factors contributing to elderly stroke patients' satisfaction with rehabilitation. Clinical Rehabilitation 2008; 22(9): 825-835.

5. Belza BT'T, Kinne S, Patrick DL, Ramsey SD. Does Adherence Make a Difference? Results From a Community-Based Aquatic Exercise Program. Nursing Research 2002; 51(5):285-91.

6. Creswell J W, Plano Clark V L. Designing and conducting mixed methods research. (2nd ed.). Thousand Oaks, CA: Sage, 2011

7. Darren George PM. SPSS for Windows Step by Step, A Simple Guide and Reference. 4th ed: Allyn \& Bacon; 4 edition (August 19, 2002) Language: English; 2003. $61 \mathrm{p}$

8. Braun V, Clarke V. Using thematic analysis in psychology. Qualitative research in psychology 2006; 3(2):77-101.

9. Van der Eijk M, Faber M J, Al Shamma S, Munneke M, Bloem B R. Moving towards patient-centered healthcare for patients with Parkinson's disease. Parkinsonism \& related disorders 2011; 17(5): 360-364.

10. Lübcke A, Martin C, Hellström K. Older adults' perceptions of exercising in a senior gym. Activities, Adaptation \& Aging 2012; 36(2), 131-146.

11. Beattie PF, Pinto MB, Nelson MK, Nelson R. Patient satisfaction with outpatient physical therapy: instrument validation. Phys Ther 2002; 82: 557-65.

12. Brokalaki E I, Sotiropoulos GC, Tsaras K, Brokal- aki $\mathrm{H}$. Awareness of diagnosis, and information-seeking behavior of hospitalized cancer patients in Greece. Supportive care in cancer 2005; 13(11): 938-942.

13. Greive A C, Lankhorst G J. Functional outcome of lower-limb amputees: a prospective descriptive study in a general hospital. Prosthetics and orthotics international 1996; 20(2): 79-87.

14. Watkins AL, Liao S J. (1958). Rehabilitation of persons with bilateral amputation of lower extremities. Journal of the American Medical Association, 166(13), 15841586.

15. Petek Šter M, Švab I, Zivcec Kalan G. Factors related to consultation time: experience in Slovenia. Scandinavian journal of primary health care 2008; 26(1): 29-34.

16. Karro J, Dent A W, Farish S. Patient perceptions of privacy infringements in an emergency department. Emergency Medicine Australasia 2005; 17(2): 117-123.

17. Patients' Rights Charter. http://www.doh.gov.za/ docs/legislation/patientsright/charter.html. (Accessed 31/8/2014)

18. Schoppen T, Boonstra A, Groothoff J W, de Vries J, Göeken LN, Eisma W H. Physical, mental, and social predictors of functional outcome in unilateral lower-limb amputees. Archives of physical medicine and rehabilitation 2003; 84(6): 803-811.

19. Pezzin LE, Dillingham TR, MacKenzie E J. Rehabilitation and the long-term outcomes of persons with trauma-related amputations. Archives of physical medicine and rehabilitation 2000; 81(3): 292-300.

20. Horgan O, MacLachlan M. Psychosocial adjustment to lower-limb amputation: a review. Disability \& Rehabilitation 2004; 26(14-15): 837-850.

21. Frierson RL, Lippmann SB. Psychiatric consultation for acute amputees: Report of a ten-year experience. Psychosomatics 1987; 28(4): 183-189.

22. Chetty V, Maharaj SS .Collaboration between health professionals in the era of antiretroviral therapy. Journal of the Association of Nurses in AIDS Care 2013; 24(2): 166-175.

23. Pohjolainen T, Alaranta $H$. Predictive factors of functional ability after lower-limb amputation. In Annales chirurgiae et gynaecologiae 1980; 80:36-39.

24. Olugbemi Olukolade T, Alao I, Adebisi A A. The Role of social support and need for achievement on psychological well-being of below the knee amputees. IOSR Journal Of Humanities And Social Science 2013; 18(1): 23-27. 